\title{
Learning Strategy for a Prospective Professional Engineer
}

\author{
Alexander CHUCHALIN \\ Tomsk Polytechnic University, Tomsk, Russia \\ chai@tpu.ru \\ Yuliya GASHEVA \\ Tomsk Polytechnic University, Tomsk, Russia \\ jvg@tpu.ru
}

\begin{abstract}
The paper proposes a learning strategy as a tool for professional development of graduate engineers. The aim of the study is to define elements of a learning strategy for prospective professional engineers and to identify a way for forming this strategy. Feedback questionnaires for certified professional engineers in Russia and two-round Delphi questionnaires for practicing engineers and evaluators involved in certification examinations are among used methods.
\end{abstract}

Keywords: learning strategy, professional engineer, continuous professional development.

\section{INTRODUCTION}

Certification of professional engineers is a feature of countries with established professional community of practicing engineers: Canada, the USA, Japan, Korea, Australia and others. It is seen as a tool for regulating and developing the engineering profession. Set and level of competencies of a graduate with a degree in engineering and a professional engineer differ according to the requirements of the Washington Accord, the International Professional Engineers Agreement and the APEC Engineer agreement implemented within the International Engineering Alliance (IEA). A lot of attention is paid to the continuous professional development (CPD) of young engineers through the mentorship and professional development programs in countries where the certification of professional engineers is one of the main instruments of engineering profession regulation. Young engineers should choose a route approved by a relevant engineering association which is in charge of profession regulation.

Engineering in Russia faces a number of challenges that have to be addressed to retain the best Russian engineering traditions. Nowadays there is no federal law concerning professional qualifications in engineering. It is an issue for a company to develop and maintain an internal qualification framework. A majority of companies have such 
regulations. Usually all technicians, technologists and engineers are examined in accordance with corporate criteria periodically. Ranks held and financial rewards are stipulated by the results of this examination. There is no consistency among corporate regulations throughout the country. The Association for Engineering Education of Russia (AEER) initiated development of a national certification and registration system based on the best international practices in certification of professional engineers and the requirements of the IEA Graduate Attributes and Professional Competencies. The Association involves major stakeholders in discussion of the issue: the State Duma (the national legislative body), the Government of the Russian Federation, the Chamber of Commerce and Industry of the Russian Federation, the Russian Union of Scientific and Public Organizations, engineering universities and companies. In 2008 the AEER received an official proposal to join the APEC Engineer Register and applied for its membership at the International Engineering Congress organized by the International Engineering Alliance in Kyoto in 2009. The first operational office - the Centre for International Certification of Engineering Education and Profession - was opened at Tomsk Polytechnic University. The next step of the system development was the transfer of operational functions to the regional Chamber of Commerce and Industry for more active involvement of employers in certification activities. At present over one hundred of engineers are certified with the title APEC Engineer. This first stage of certification development in Russia can be titled 'normative'. Standards and procedures for assessment provided by public and professional associations are the core of professional engineers' certification. Formation of professional engineer culture remains a challenge for academic institutions, industry and other stakeholders.

Graduated engineers should be more self-sufficient in determining personal professional development. A significant part of applications for the professional engineer status was rejected because of lack of evidence of professional development in a necessary scope. Furthermore some certified engineers became not eligible for recertification with the same reason. It is supposed that implementation of a relevant learning strategy can be an effective tool for professional development of graduates and experienced engineers.

\section{THEORETICAL FRAMEWORK}

Litzinger, Lattuca, Hadgraft, and Newstetter (2011) highlighted features of expertise in engineering:

- The knowledge of experts is organized around key concepts to be applied to novel problems.

- The knowledge is linked to the context in which it is useful.

- Everyone needs to invest 10 years of active engagement in a domain to become expert.

- The practice has to be performed with the intention of improving a skill.

- Multiple opportunities should be provided for learners to practice their skills on authentic tasks that require the integrated application of various knowledge and skills.

- Learning experience should be arranged to identify the knowledge and skills needed for expert practice, as well as to develop that knowledge and skill set. 
These principles can form a basis for mentoring programs.

Siemens (2004) specified limitations of the most often utilized learning theories (cognitivism, constructivism and behaviourism) and proposed connectivism as a learning theory for nowadays. The main factors are shrinking half-life of knowledge and technologies proliferation. Among principles of connectivism outlined by Siemens these ones should be emphasized:

- Capacity to know more is more critical than what is currently known.

- Learning is a process of connecting specialized nodes or information sources.

- Nurturing and maintaining connections is needed to facilitate continual learning.

- Ability to see connections between fields, ideas, and concepts is a core skill.

- Decision-making is itself a learning process. Choosing what to learn and the meaning of incoming information is seen through the lens of a shifting reality. While there is a right answer now, it may be wrong tomorrow due to alterations in the information climate affecting the decision.

So, information technologies are an integral part of life-long learning and a tool for a learning strategy implementation.

General tips on effective study strategies (Cottrell, 2013) can be also applied in forming a learning strategy. They cover attitudes to learning and techniques to organize learning activities. Comparative analysis of guidelines on continuing professional development applied by the members of the International Engineering Alliance (Chinese Institute of Engineers, 2012, Engineers Australia, 2009, Engineers Canada, 2004, Engineers Ireland, 2013) grounded the proposed guidelines on recognition of professional development of engineers in Russia.

\section{METHOD}

To reveal effective forms of professional development of certified engineers a feedback questionnaire was composed and sent to all engineers registered in the Russian section of the APEC Engineer register. The response was got from one third of engineers (56 persons). The survey of proposed guidelines on recognition of professional development of engineers was arranged with two-round Delphi questionnaires distributed among certified engineers and evaluators involved in certification exams. Recommendations on improvement of the guidelines were also received within application procedures to the APEC Engineer agreement and the International Professional Engineers Agreement.

\section{RESULTS}

A graduate needs a learning strategy if his / her background and level of competence are inadequate for being certified as a professional engineer. For the purposes of this study a learning strategy is considered to be a general plan of learning activities for a long period of time (2-7 years) for achieving a challenging goal. 
Certification as a professional engineer can be the goal of a learning strategy. $43 \%$ of respondent claimed that the certification as a professional engineer is an impetus for professional development. It should be taken into account that the wording of answers for the question 'Your reasons for taking certification procedures' was free. Other reasons of taking certification are provided in the diagram 1 below.

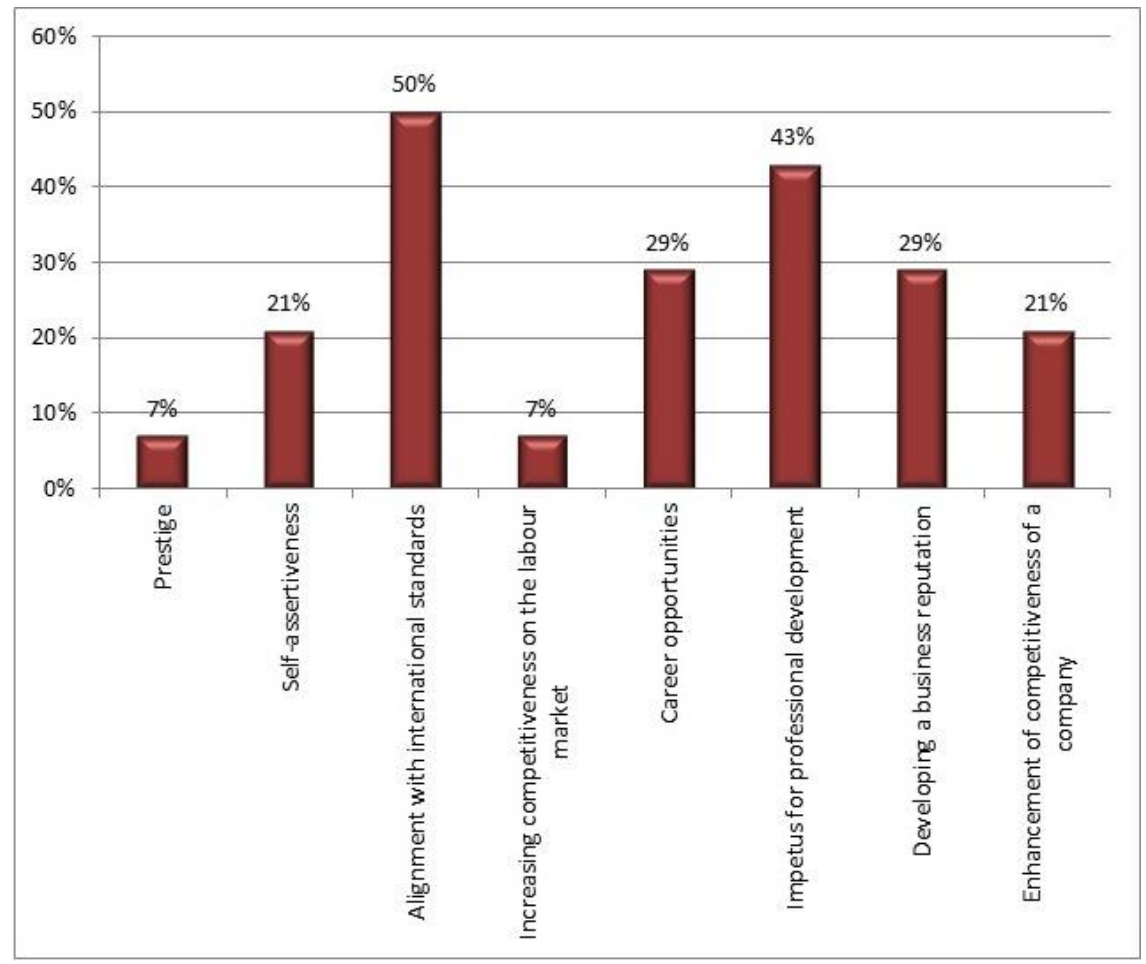

Figure 1: Reasons for taking certification procedures

Feedback received from certified engineers reveals that certification criteria for professional engineers adopted by the IEA provide a comprehensive framework for learning strategy building. $94.6 \%$ of respondents agree that there is no need to enlarge the list of competencies required from a professional engineer according to the IEA standards. According to the questionnaire results the five most effective professional development activities are:

- mentoring (71.4\%),

- professional development programmes delivered by HEIs $(62.5 \%)$,

- $\quad$ short-term workshops (35.7\%),

- long-term training in a non-affiliated company to master best practices (26.8\%),

- $\quad$ R\&D activities $(25.0 \%)$. 
Complex learning strategy formation is fostered with recognition of non-formal and informal learning by organizations responsible for regulating the profession. The following guidelines (table 1) were elaborated upon profound review of international practice of formal, non-formal and informal professional development recognition and consideration of national traditions. The guidelines were approved at the AEER Administrative Board Meeting on the 19th of November, 2013. Necessity in conversation of CPD activities in hours is entailed by the requirement for professional engineer to perform professional development no less than 50 hours a year.

\section{Table 1. AEER guidelines on recognition of professional development of engineers}

\begin{tabular}{|c|c|c|c|}
\hline CPD Activity & Level & $\begin{array}{c}\text { Type of } \\
\text { Involvement }\end{array}$ & Amount of Hours \\
\hline $\begin{array}{l}\text { Ph.D. or D.Sc. } \\
\text { studies }\end{array}$ & $\begin{array}{l}\text { Russian and } \\
\text { International }\end{array}$ & $\begin{array}{l}\text { Candidate } \\
\text { for a degree }\end{array}$ & $\begin{array}{c}\text { Equivalent to the required } \\
\text { CPD activities for three } \\
\text { years }\end{array}$ \\
\hline \multirow{4}{*}{$\begin{array}{c}\text { Educational } \\
\text { programmes on } \\
\text { professional } \\
\text { development }\end{array}$} & \multirow[t]{2}{*}{ Russian } & Learner & $\begin{array}{c}\text { Equivalent to indicated } \\
\text { academic hours }\end{array}$ \\
\hline & & Teacher & 2 hours for 1 academic hour \\
\hline & \multirow[t]{2}{*}{ International } & Learner & $\begin{array}{c}\text { Equivalent to indicated } \\
\text { academic hours }\end{array}$ \\
\hline & & Teacher & 3 hours for 1 academic hour \\
\hline \multirow{4}{*}{$\begin{array}{l}\text { Seminars and } \\
\text { training }\end{array}$} & \multirow[t]{2}{*}{ Russian } & Learner & $\begin{array}{c}\text { Equivalent to indicated } \\
\text { academic hours }\end{array}$ \\
\hline & & Trainer & 2 hours for 1 academic hour \\
\hline & \multirow[t]{2}{*}{ International } & Learner & $\begin{array}{c}\text { Equivalent to indicated } \\
\text { academic hours }\end{array}$ \\
\hline & & Trainer & 3 hours for 1 academic hour \\
\hline \multirow[t]{6}{*}{ Conferences } & \multirow[t]{3}{*}{ Russian } & Participant & 10 \\
\hline & & Reporter & 20 \\
\hline & & $\begin{array}{l}\text { Member of } \\
\text { the board of } \\
\text { editors }\end{array}$ & 40 \\
\hline & \multirow[t]{3}{*}{ International } & Participant & 15 \\
\hline & & Reporter & 30 \\
\hline & & $\begin{array}{l}\text { Member of } \\
\text { the board of } \\
\text { editors }\end{array}$ & 60 \\
\hline
\end{tabular}




\begin{tabular}{|c|c|c|c|}
\hline \multirow{2}{*}{$\begin{array}{c}\text { Training in } \\
\text { non-affiliated } \\
\text { company }\end{array}$} & Russian & Trainee & Up to 100 hours \\
\hline & International & Trainee & Up to 6 hours per day \\
\hline \multirow[t]{2}{*}{ Invention } & $\begin{array}{l}\text { Russian and } \\
\text { International }\end{array}$ & Author & 50 \\
\hline & $\begin{array}{c}\text { Russian and } \\
\text { International }\end{array}$ & Author & 25 \\
\hline $\begin{array}{l}\text { Involvement in } \\
\text { grant research }\end{array}$ & $\begin{array}{l}\text { Russian and } \\
\text { International }\end{array}$ & Researcher & Up to 50 hours \\
\hline $\begin{array}{c}\text { Membership in } \\
\text { professional } \\
\text { societies }\end{array}$ & $\begin{array}{l}\text { Russian and } \\
\text { International }\end{array}$ & Member & Up to 10 hours \\
\hline $\begin{array}{c}\text { On-the-job } \\
\text { training (e.g., } \\
\text { technology } \\
\text { modernization) }\end{array}$ & $\begin{array}{l}\text { Russian and } \\
\text { International }\end{array}$ & Trainee & Up to 50 hours \\
\hline \multirow{2}{*}{$\begin{array}{l}\text { Writing articles } \\
\text { for publication } \\
\text { in professional } \\
\text { journals }\end{array}$} & Russian & Author & 20 \\
\hline & International & Author & 40 \\
\hline \multirow{2}{*}{$\begin{array}{l}\text { Writing } \\
\text { monographs, } \\
\text { study books }\end{array}$} & Russian & Author & $\begin{array}{l}40 \text { hours for } 40,000 \\
\text { typographical units }\end{array}$ \\
\hline & International & Author & $\begin{array}{l}60 \text { hours for } 40,000 \\
\text { typographical units }\end{array}$ \\
\hline \multirow{2}{*}{$\begin{array}{l}\text { Review of } \\
\text { articles, } \\
\text { research studies }\end{array}$} & Russian & Reviewer & $\begin{array}{l}3 \text { hours for } 40,000 \\
\text { typographical units }\end{array}$ \\
\hline & International & Reviewer & $\begin{array}{l}4,5 \text { hours for } 40,000 \\
\text { typographical units }\end{array}$ \\
\hline $\begin{array}{c}\text { Review of } \\
\text { degree thesis }\end{array}$ & $\begin{array}{l}\text { Russian and } \\
\text { International }\end{array}$ & Reviewer & 4 hours for 1 reviewed thesis \\
\hline $\begin{array}{c}\text { Review of study } \\
\text { books }\end{array}$ & $\begin{array}{l}\text { Russian and } \\
\text { International }\end{array}$ & Reviewer & $\begin{array}{l}4 \text { hours for } 40,000 \\
\text { typographical units }\end{array}$ \\
\hline \multirow{2}{*}{$\begin{array}{l}\text { Consulting of a } \\
\text { Bachelor or } \\
\text { Master student } \\
\text { on a graduation } \\
\text { thesis }\end{array}$} & Russian & Consultant & $\begin{array}{c}20 \text { hours for Bachelor thesis } \\
25 \text { hours for Specialist thesis } \\
30 \text { hours for Master thesis }\end{array}$ \\
\hline & International & Consultant & $\begin{array}{c}30 \text { hours for Bachelor thesis } \\
35 \text { hours for Specialist thesis } \\
40 \text { hours for Master thesis }\end{array}$ \\
\hline $\begin{array}{l}\text { Involvement in } \\
\text { development of }\end{array}$ & $\begin{array}{l}\text { Russian and } \\
\text { International }\end{array}$ & Consultant & Up to 10 hours \\
\hline
\end{tabular}




\begin{tabular}{|c|c|c|c|}
\hline $\begin{array}{c}\text { a degree } \\
\text { programme }\end{array}$ & & & \\
\hline $\begin{array}{l}\text { Supervision of } \\
\text { student } \\
\text { traineeship }\end{array}$ & $\begin{array}{l}\text { Russian and } \\
\text { International }\end{array}$ & $\begin{array}{l}\text { Supervisor, } \\
\text { trainer }\end{array}$ & $\begin{array}{l}1 \text { hour for } 1 \text { week per } 1 \\
\text { student of } 1^{\text {st }}-3^{\text {d }} \text { year } \\
\text { (Bachelor students, } \\
\text { Specialist students) } \\
3 \text { hours for } 1 \text { week per } 1 \\
\text { student of } 4^{\text {th }}-5^{\text {th }} \text { year } \\
\text { (Bachelor students, } \\
\text { Specialist students), Master } \\
\text { student or intern }\end{array}$ \\
\hline $\begin{array}{l}\text { Elaboration of } \\
\text { questions for } \\
\text { professional } \\
\text { engineers } \\
\text { certification } \\
\text { examination } \\
\text { (for certified } \\
\text { engineers only) }\end{array}$ & $\begin{array}{l}\text { Russian and } \\
\text { International }\end{array}$ & Author & $\begin{array}{l}1 \text { hour for } 4 \text { questions of } \\
\text { written exam }\end{array}$ \\
\hline $\begin{array}{l}\text { Involvement in } \\
\text { examination of } \\
\text { professional } \\
\text { engineers }\end{array}$ & $\begin{array}{l}\text { Russian and } \\
\text { International }\end{array}$ & Examiner & $\begin{array}{l}\text { Oral examination: } 1 \text { hour for } \\
1 \text { interviewee } \\
\text { Written examination: } 1 \text { hour } \\
\text { for } 1 \text { test }\end{array}$ \\
\hline
\end{tabular}

There is no obvious replication of international experience in CPD hours allocation, however main types of formal, non-formal and informal professional development activities are listed. The main emphasis is put on the outcomes of these activities, so candidates for the professional engineer title or professional engineers wishing to renew their certificates are motivated to be involved in continuous professional development. These guidelines are a subject for a further periodic review.

\section{CONCLUSION}

It is supposed that examination is not a crucial function of a system for certification of professional engineers. An essential function of the system is the process of professional engineers formation. Provision of an impetus and resources for professional development means engineering body improvement. A learning strategy of a graduate, who wishes to be certified as a professional engineer, should at least encompass self-assessment according to the certification criteria and the IEA Graduate Attributes and Professional Competencies, a plan of recognized CPD activities for two years minimum and reflection on its implementation. According to the survey results one of the most effective tools for forming a learning strategy is mentoring by experienced engineers.

There are two issues among prospects of further research. The first one is to determine can be a mentor effectively substituted by an intellectual on-line system to assist graduate 
engineers in professional development. The second one is to find out impetuses for engineers to systematically reflect on their competence and contribute to professional community improvement.

\section{REFERENCES}

Chinese Institute of Engineers. (2012). Criteria of Continuing Professional Development. Taipei: Chinese Institute of Engineers.

Cottrell, S. (2013). The study skills handbook. Basingstoke: Palgrave Macmillian.

Engineers Australia. (2009). Continuing professional development (CPD) policy. $\begin{array}{llll}\text { Retrieved } & \text { September } & 23, & \text { from }\end{array}$ http://www.engineersaustralia.org.au/sites/default/files/shado/About\%20Us/Overview/Gov ernance/Policies/CPD\%20Policy.pdf

Engineers Canada. (2004). Guideline on continuing professional development and continuing professional competence for professional engineers. Retrieved September 23, 2014,

from http://www.engineerscanada.ca/sites/default/files/guidelinecompetency2004.pdf

Engineers Ireland. (2013).Continuing engineering education for professional development and career advancement. Retrieved September 23, 2014, from https://www.engineersireland.ie/EngineersIreland/media/SiteMedia/cpd/training/fpp/EI_C PD_FutureProfessionalsFinal_web.pdf

International Engineering Alliance. (2013). Graduate Attributes and Professional Competencies. $\quad$ Retrieved September 23, 2014, from http://www.ieagreements.org/GradProfiles.cfm

Litzinger, T. A., Lattuca, L. R., Hadgraft, R. G., \& Newstetter, W. C. (2011). Engineering education and the development of expertise. Journal of Engineering Education, 100(1), 123-150.

Siemens, G. (2004). Connectivism: A learning theory for the digital age. Retrieved September 23, 2014, from http://www.elearnspace.org/Articles/connectivism.htm 